\title{
Cross-dressing among medieval Ashkenazi Jews
}

Confirming challenged group borders

\author{
Lena Roos
}

Aвstract - This article deals with explicit permissions for two types of cross-dressing found in the thirteenth-century ethical tract Sefer Chasidim. In order to avoid being sexually assaulted, female Jewish travellers were allowed to disguise themselves as $a$. Christians, even as nuns, or $b$. men. This contradicts biblical and rabbinical prohibitions against such practices. These textual passages are discussed, set against the Jewish and Christian medieval discourse on dress and identity, and they are also related to other contemporary source texts that show that the borders between men and women, and Jews and Christians, as distinct and separate groups were at this time being contested. The author concludes that these permissions should not be seen as ways of transcending the boundaries of the group, but rather as part of a discourse that served to strengthen such boundaries.

While travelling, a woman heard that a group of gentiles was approaching. She feared that they might rape her. Under such circumstances, she is permitted to dress as a nun so that they will believe that she is a nun and not rape her. If she learns that Jewish robbers are approaching, she is likewise allowed to dress in the style of the gentiles and claim that she is a gentile. She is permitted to threaten that she will cry out and report them [to the authorities]. She is permitted to scream for help right away so that gentiles will come and save her, even if the gentiles will kill the [Jewish] attackers. (Wistinetzki I924: §26I; very similar text in Margaliot I 957: §702)

The Torah states: 'A woman shall not put on a man's apparel, nor shall a man wear a woman's garment' (Deut. 22:5). Nevertheless, if an enemy army is laying siege to a city, or if, on the road, the enemies would find out that they are women, and then they would rape them, the women they should put on men's cloth- ing and even carry swords in order to make them think that they are men. And if twenty [non-Jewish] men should come, and there are only ten [Jewish] men and about forty women, the women should all gird themselves with swords to make them [= the non-Jews] think that they are men and thus not harm them. (Wistinetzki I924: §206)1

These quotations contain the essence of the topic of this article. In order to avoid being

1 Both quotations are from Sefer Chasidim. In all references to Sefer Chasidim I have compared the Parma version, edited by Jehuda Wistinetzki, to the Bologna version, edited by Reuven Margaliot. The other edition, Margaliot I957: \$200, has a text that differs slightly but with the same basic message, ending: 'And if there are only ten men and a large number of women, the women should all gird themselves with swords to make them [= the non-Jews] think that they are men and thus not harm them.' All translations from the original Hebrew are mine. 
raped, according to the thirteenth-century book Sefer Chasidim, Jewish women were allowed to practise two different kinds of 'cross-dressing': a. disguising themselves as Christians, even as nuns, and $b$. disguising themselves as men.

This article will deal with the background, Jewish as well as Christian, to this permission, which seems to contradict explicit prohibitions in the Hebrew Bible. I will also attempt to analyse these passages from the perspective of Judith Butler's theory of gender as performative, rather than ontological and prediscursive, and of how repeated actions as well as discourse serve to uphold a binary system of two clear gender categories. Butler sees gender as the effect of such a system, rather than its cause (Butler I 999: XV, I I , 43, I 73). Or in Butler's words: 'Gender is always doing, though not a doing by a subject who might be said to pre-exist the deed' (ibid. 33). Butler poses the question: 'To what extent do regulatory practices of gender formation and division constitute identity, the internal coherence of a subject, indeed the self-identical status of the person?' (ibid. 23). The answers that emerge from her various publications on the matter can be summarised as: to a great extent. Butler also claims that the act of differentiating the two poles of the binary system also serves to consolidate each term, making the group appear more coherent (ibid. $3 \mathrm{I}-2$ ). Men are men and women are women, with all the characteristics that go with that category. In this study I will also attempt to use Butler's theory on the binary categories of Jews and Christians in medieval Christian society. ${ }^{2}$

2 When it comes to understanding Butler and applying her theories to a medieval material, I am indebted to my colleague Malin Ekström, whose knowledge of the works of Butler, and in general of queer and gender theory, by far surpasses mine. Malin Ekström's careful reading of this article at various stages has been very helpful. I would also like to acknowledge that the writing of this article

\section{Crossing boundaries}

There are several interesting elements in the two quotations above. Starting with the first: women are allowed to disguise themselves, not only as Christians, but even as nuns. Disguising themselves as Christians must have entailed exposing themselves to risks from the point of view of traditional Jewish practice, such as being expected to eat forbidden foods, perform forbidden tasks on the Sabbath, or participating in the Christian cult. They are also allowed to call for help should they be attacked by fellow Jews, although this would entail exposing these Jews to mortal danger. This is surprising for several reasons. First, it presents an interesting reversal of roles, against what might be expected: Jewish men are presented as violent and sexually threatening, and gentiles are presented as the rescuers from this danger. Secondly, in this case protecting the chastity of the women overrides group solidarity.

The women are also allowed to dress as men, something which goes against an explicit prohibition in the Torah: 'A woman shall not wear a man's apparel, nor shall a man put on a woman's garment; for whoever does such things is abhorrent to the Lord your God' (Deut. 22:5, NRSV).

While the passages quoted above concern women, there is also a similar one allowing young boys 'who have not yet grown a beard' the same two kinds of cross-dressing: they were allowed to disguise themselves as Christians or women (Wistinetzki I924: §207; Margalioth: \$20I). So both women and young boys were allowed to dress as Christians as a safety precaution. This way they could escape negative treatment stemming from the fact that they were Jews. It is unclear what the reason for this

was made possible by a generous research grant by the Bank of Sweden Tercentenary Foundation. 
negative treatment was. Was it due to general anti-Jewish tendencies, or were Jews for some reason seen as more likely victims of highway robbery? The takkanot (regulations) passed by the Jewish communities of Speyer, Worms and Mainz during the thirteenth century generally forbade cutting the hair or shaving the beard in a non-Jewish fashion, as well as dressing like the gentiles (Rubens r 967: 94).

It is an interesting paradox that whereas women were allowed to dress as men for protection, young men were allowed to dress as women for protection. Possibly the explanation lies in what they were protected from. The passages at the beginning of this article explicitly refer to sexual assault, whereas no such reference to sex is found in the passage concerning the young men. There it merely says that they are allowed to dress as women in 'order to be saved' (להנצל), and to dress as Christians in order to 'lead the enemies astray' (להתעות האויבים). It is possible that the preferred target for robbers was Jewish men, for instance merchants. That way young Jewish men would be less at risk if they disguised as either Jewish women or as Christian men.

\section{The text and its context}

Sefer Chasidim ('The Book of the Pious') is an ethical tract containing the teachings of the Jewish group Chasidei Ashkenaz ('The Pious of Ashkenaz') from the twefth and thirteenth centuries. The book has survived in two versions; I have used the so-called Parma version which is believed to be the more original. Sefer Chasidim is a comprehensive guide which gives practical and pragmatic advice on how a pious Jewish man should conduct his life in an number of different arenas: how to choose a teacher and a wife, how to relate to gentiles, how to dress, speak, pray, work and even to sleep (Dan 2007).

Chasidei Ashkenaz was a religious and social movement which sought to influence contemporary Jewry in two ways: through the publication of ethical literature, encouraging Jews towards a meticulous observance of the Jewish law and adherence to its moral values, and through composition of esoteric, mystical literature. The movement had its first base in the towns of Regensburg, Speyer, Worms and Mainz, but came to influence most of the Jewish communities in Germany, and in some parts of France as well (Dan et al. 2007: 386). ${ }^{3}$ Earlier scholarship on this group has suggested that many elements of its ideology and practice were influenced by contemporary Christianity. So, for instance the practice of mortification of the body as a form of repentance is believed to have been influenced by similar practices among Christian monks (ibid. 388).

\section{Dress and identity in the Middle Ages}

As in our own time, dress was used to signal identity in the Middle Ages. A stark difference, however, is that while the choice of clothing and the related signals to a great extent is left to the individual in our time, in the Middle Ages this was in many respects beyond the control of the individual. There were rules as to what type of dress and overall appearance (e.g. hair style, beard) was allowed or appropriate depending on the individual's sex, age, social class, marital status and religion (Weichselbaumer I 999: 340).

What do we know of how medieval Jews and Christians dressed? What might a change in appearance such as is found in the quotations above have entailed? The scholarship on medieval costume is fraught with difficulties and uncertainties. Very few medieval pieces of clothing have been preserved, and those which remain to our day are often unique pieces of great value,

3 It is hard to determine the extent of the influence of the Chasidei Ashkenaz. Haym Soloveitchik (2002) believed that its influence was minimal. Ephraim Kanarfogel (1992) disagreed and thought it was considerable. 
not the everyday clothes most people wore. The main sources for knowledge about medieval costume are therefore medieval pictures, such as illuminations in books, murals and other paintings, and sculptures, for instance on graves, and medieval texts which mention clothes.

Both these sources are problematic. We cannot know that the clothes displayed in the works of art reflect those that were worn in that area during the period when the painting was made. There could for instance be a tendency towards conservatism in how clothing was painted. It is also possible that the artist came from another area and his artwork reflected the fashion there rather than the clothing worn where the painting was made. A further factor to be taken into account is that medieval art was often symbolic. Elements such as clothing could be used to symbolically indicate the character, age or standing of a person.

A problem with texts that speak of clothing is that it is often difficult to know what exactly is being referred to, since the terminology is unclear. The same term can refer to pieces of clothing that can vary in shape depending on the time period and geographical area. Sometimes the opposite occurs: different terms can be used for similar pieces of clothing. The same lack of certainty remains when it comes to some of the medieval terminology for materials and techniques. ${ }^{4}$

Much scholarship has been dedicated to the history of medieval clothing over recent decades, as is evident, for instance, from the appearance of the scholarly, interdisciplinary journal Medieval Clothing and Textiles, which

4 For a longer general discussion on the difficulties in pursuing scholarship on medieval dress, see Vavra I 988 or Piponnier and Mane I 997: 3-13. On the lack of clarity and consistency in medieval (and modern scholarly) terminology, see von Wilckens I 988. On communication through medieval dress, see Burns 2004 and Elliott I99I. first appeared in 2005. Most of this scholarship, however, has been dedicated to the study of costume in Christian society. ${ }^{5}$ Much less attention has been dedicated to the study of Jewish clothing customs during this period, probably in part owing to the lack of sources. 6 One of the most important contributions is Elisheva Baumgarten's book Practicing Piety in Medieval Ashkenaz: Men, Women, and Everyday Religious Observance (2015), where she dedicates a chapter to the way the Jews in medieval Ashkenaz dressed. She describes how Jews and Christians communicated in similar ways through their clothing. She also concludes that although the clothing of Jews and Christians in this context seems to have been very similar, there were still differences, sometimes subtle, that indicated the religious affiliation of the person wearing the garment. I discuss sources below that testify to efforts by both Jewish and Christian authorities to prescribe distinguishing clothing for the Jews, which can give us an indication of the extent to which the clothing of Jews and Christians differed.

The use of the term 'cross-dressing' for the practices outlined in the quotations above needs to be specified. It should be made clear that what is intended is the practice, under certain circumstances, of hiding one's true identity by adopting a disguise that will allow a person to escape unharmed from a dangerous situation. It does not entail any desire to assume that other identity, for instance for women to become men or live the life of men, or to become Christians. This means that this is not the same as cross-dressing or transvestitism in modern society, which in a sense aims at the opposite. Such cross-dressing rather tries to reveal a person's true identity, or certain aspects of it.

5 A classical work is Houston I 939. For more modern studies, see e.g. Crowfoot et al. 1992 and Heller 2007.

6 A classical work is Rubens 1967. 


\section{Gender-reversing cross-dressing}

The passage quoted at the beginning of the article is one of several explicit permissions for gender-reversing cross-dressing found in Sefer Chasidim. Another passage tells of a very beautiful woman who travelled with her husband. She made a fake beard from human hair, to disguise herself as a man. Sefer Chasidim notes: 'Those who saw her thought she was a man. Thus she was saved' (Wistinetzki 1924: §207; Margaliot I957: §201). This recourse was obviously acceptable to the author of Sefer Chasidim, at least under certain circumstances.

We shall start by examining the Deuteronomistic prohibition on gender-reversing crossdressing in its original context in the Hebrew Bible:

\section{לא יהיה כלי גבר על אשה}

A woman shall not put on a man's apparel, ולא ילבש גבר שמלת אשה

nor shall a man wear a woman's garment;

כי תועבת יהוה אלהיך כל עשה אלה

for whoever does such things is abhorrent to the Lord your God. (Deut. 22:5)

There are several difficulties in determining the exact meaning of this passage. The first part of the verse literally claims that something called keli gever כלי גבר (here translated as 'a man's apparel', following the NRSV), should not 'be upon' (יהיה על) a woman ('ishah האש ). In the following part the word gever occurs again (here translated as 'a man'), stating that he should not 'wear' (ילבש) 'a woman's garment'.

We may first note that the words here translated as 'woman' and 'man' have different nuances. Whereas 'ishab is a general term for female human being, gever on the other hand has a certain nuance. The Deuteronomistic redactor has not chosen the corresponding male version of 'ishah, 'ish, but rather the more specific term gever, probably a conscious choice given that this is the only time it occurs in Deuteronomy. In the other 64 occurrences in the Hebrew Bible, the word gever is usually associated with either physical strength and virility or obedience to God (Vedeler 2008: 47 I-2). The word keli has the general meaning 'article, utensil, vessel'. In modern translations of the Bible it is often understood as a reference to clothing, mainly because later rabbinical literature use it in the plural, meaning 'garment'. Such a translation also seems logical as a parallel to the second part of the verse, which clearly refers to clothing. The Deuteronomistic author, however, seems to consciously make a difference between the two different parts of the verse, indicating that they are not completely parallel: in the first part he uses the word keli instead of some term that unambiguously refers to clothing, like the word שמלה ('garment') as in the second part of the verse. We should also note that he does not use the normal verb for 'wear' (לבש) which occurs in the second part of the verse, but rather 'be upon'. Some scholars have therefore suggested that keli should rather be understood as a reference to a weapon, an interpretation which is supported by the choice of the word gever which in all Semitic languages where it is attested is associated with strength and power, rather than using the more neutral 'ish (Vedeler 2008: 47I). Harold Torger Vedeler suggests:

The verse is more than a simple prohibition of particular wardrobes, and in no way addresses the issue of women wearing masculine garments, since in the culture of ancient Israel the clothing of men was less associated with gender than was the clothing of women. Rather, the verse reflects the most basic ideology of gender in Israelite society, and to this end it distinguishes not simply between male and female but also between different qualities of men. (Vedeler 2008: 473) 
He therefore argues that the verse should be read as a prohibition against women donning weapons, and thereby using the symbols of the superior man (gever), and against the superior men associating themselves with the symbols of women, which in the ancient Near East were believed to have the power to weaken their masculinity (Vedeler 2008: 473). An added reason for this prohibition was to separate the Israelites from other cultures in the contemporary Near East from which we have evidence of cultic cross-dressing, or at least sexually ambiguous persons with cultic functions (ibid. 464-8). This interpretation is strengthened by the fact that Deuteronomy has more such condemnations of 'abominations' than any other book in the Hebrew Bible, and many of them concern practices that occurred in the cults of surrounding peoples.

The Talmud addresses both interpretations of keli, both as clothing and as weapon. It starts by stating that merely wearing the clothes of the other sex is not an abomination. Doing so in order to mix with the other sex in an improper way, however, is. After that the text introduces a dissenting view: that of Rabbi Eliezer ben Yaakov, who reads the first part of the passage as a prohibition against women bearing arms and going to war, and the second as a prohibition against men embellishing themselves with the embellishments of women (Vedeler 2008: 468). Several medieval Jewish commentators follow the Talmud in regarding this as a prohibition which is meant to prevent men and women from mixing for illicit sexual purposes (Rashi ad loc.; Rabbi Samuel ben Meir Rashbam ad loc). ${ }^{7}$

The second passage from Sefer Chasidim, quoted at the beginning of this article, seems

7 Abraham Ibn Ezra interprets the first part of the verse as a prohibition against women going to war, which will lead to immorality, the second part as a prohibition against men mixing with women for indecent purposes, Ibn Ezra ad loc. to encompass both interpretations, that the Deuteronomistic verse refers both to women wearing men's clothes and donning weapons, since, in apparent contradiction with the biblical passage, it explicitly allows both, under certain circumstances. I have not found any other Jewish source, earlier than Sefer Chasidim, which issues such permission. Still, it is obvious that the author of Sefer Chasidim views this as an exception to the general rule prohibiting cross-dressing. Under these particular circumstances, it is allowed.

How was this prohibition viewed in Christian society during the Middle Ages? In the Vulgate, the most commonly used Latin translation in medieval Western Christian society, the text hides the difficulties present in the original Hebrew, and interprets it simply as a prohibition against cross-dressing for both sexes, recalling how the verse is usually rendered in modern translations:

\section{Non induetur mulier veste virili nec vir utetur veste feminea abominabilis enim apud Deum est qui facit haec.}

In medieval Christian society, in theory the Deuteronomistic prohibition was still valid. As such it was repeated over and over in canon law (Hotchkiss I996: I I). 8 In practice there was a greater tolerance towards women dressing as men than the opposite. This should be ascribed to the medieval Christian perception of males as superior to females. This means that women who impersonated men were seen as striving to become better persons, more rational, more holy (Bullough 2000: 225, 227). A popular display of this can be found in the legends of

8 See for instance the decrees of Burchard of Worms (d. I025/6), PL I 40, col. 805 and of Gratian (twelfth century), PL I 87, col. I 65 (Burchard of Worms 1996, Gratian I996). 
many female saints who disguised themselves as men, lived lives completely devoted to God, and whose real sex was only discovered after their death (ibid. 228-30). By their cross-dressing, these women escaped life as wives and mothers, which in many medieval legends of female saints is described as a burden and an obstacle to spiritual life (Hotchkiss I 996: 22). They also gained access to religious offices and arenas where women were otherwise prohibited. The most famous case is probably the legend of Pope Joan, recorded by several thirteenth-century chroniclers (Bullough 2000: 230). In some of these cases there is also a parallel to the Jewish woman in the passage from Sefer Chasidim who had made a fake beard for herself, as part of her disguise. In some of these Christian saints' legends, the women miraculously grew beards (Garber 1992: 214). The part about growing a beard in the Christian legends is not merely a case of disguise, but also a way of disfiguring a beautiful woman, as a way of escaping marriage (Hotchkiss r 996: 23).

These legends were popular, as is seen by the many versions of the stories, and by the fact that during the thirteenth to fifteenth centuries vernacular versions appeared in many parts of Europe (Hotchkiss i 996: I 5). There were also a couple of such saints of medieval European origin, for instance Hildegund of Schönau (d. I 88 ) and Angela of Bohemia (early thirteenth century) who were all relatively close to Sefer Chasidim in time and place (ibid. I5-16). It can be noted though that at least in the case of Hildegund of Schönau, the medieval legends both resemble and differ from their earlier models, mainly in that the authors betray an ambivalence towards the saint. She is praised for having denied her womanhood, but is still described in a not entirely positive way, and these negative characteristics are attributed to her being a woman. Although dressed as a man, she cannot escape her female weaknesses, one might say (ibid. 34, 38, 4I, 44).
Another parallel is seen in the motive for cross-dressing. Several of the quotations from Sefer Chasidim mention travelling as a special circumstance when cross-dressing may be allowed, or even as necessary in order to preserve a woman's virtue. Likewise, a common reason for cross-dressing, given in the accounts of Christian saints, is travel, in particular pilgrimage to the Holy Land (Hotchkiss I 996: 39).

A famous exception to this relative tolerance towards cross-dressing women in Christian society is of course Joan of Arc. In her case her cross-dressing was among the charges raised against her. Various reasons can be adduced for why she was judged so severely. One may be that in her cross-dressing, she did not aspire merely to a pious and humble life in a monastery or as a hermit, like many of the other saints, but aimed rather to enter another thoroughly male arena: that of war, which also in her case meant a change of social class (Garber I 992: 2 I 5). Still, according to one of the early accounts of Joan's life, Chronique de la Pucelle (c.1467), Joan stated that one of the reasons why she donned men's clothing was that this way she did not arouse the desires of the men she was in such close proximity with, since they fought the English together (Hotchkiss I996: 52-3). Another reason why the authorities condemned her may have been that unlike other medieval women who claimed to convey a message from God, such as for instance St Bridget of Sweden, who came from the highest nobility, Joan of Arc rose from humble circumstances. She did not have access to the 'support groups' who could defend her when accused of heresy.

The motif of cross-dressing women in a Christian context was not only limited to saints' lives. In the medieval secular literature too from Christian Europe we find accounts of women who dress as men. A common theme in these stories is that this is a strategy adopted by women who have been deserted by their husbands, as a way of going out into the world in 
order to win their husbands back or to save them from danger (Peters I 999: 29I).

Christian men who dressed as women, on the other hand, were viewed with suspicion by medieval Christian society. The most common reason medieval writers could see for such a behaviour, which reduced them to a lower status, was that these men meant to gain access to all-female arenas, in order to have extramarital sexual contacts with women (Bullough 2000: 225 ). This parallels the writings of the medieval rabbinic commentaries on the passage in Deuteronomy, which see the prohibition on cross-dressing as something aimed at preventing the illicit mixing of the sexes.

Sometimes Christian men who cross-dressed were also accused of being weak and effeminate, or of being associated with witchcraft (Bullough 2000: 227, 233). Some forms of cross-dressing were nonetheless accepted, such as men dressed as women having comical functions during festivals or carnivals or men acting the parts of women in the medieval theatre (ibid. 234-6).

There is, however, at least one example from a medieval Christian theologian who explicitly allows cross-dressing, when it is done for a greater cause. Thomas Aquinas writes:

And thus, of itself it is sinful for a woman to wear male clothing, or vice versa, especially since this can be a cause of lasciviousness. And it is particularly prohibited in the law because the gentiles used to make use of such changes of attire for the superstition of idolatry. Nonetheless, this can be done without sin at any time because of some necessity, or to hide from enemies, or because of lack of other clothing, or for some such thing of this nature. (Summa Theologiae, 2, 2, I69).

Thomas Aquinas is interesting, especially since he is relatively close in time and place to Sefer Chasidim.
To summarise: a classical Jewish interpretation of Deuteronomy 22:5 is that it is a prohibition against cross-dressing in order to prevent women and men from mixing in an improper way. This motive for men to wear women's clothing, to gain access to women for sexual purposes, is also found in medieval Christian sources. Just like in contemporary Christian society, Sefer Chasidim is more permissive when it comes to women wearing men's clothes than the reverse. Unlike in the Christian legends of female saints, the type of cross-dressing mentioned in Sefer Chasidim does not have as its aim to gain access to arenas and life-styles which otherwise would be inaccessible to women, such as male monastic circles in the Christian context. Still, it can be argued that the women in Sefer Chasidim use the male disguise as a means to transcend one of the limitations placed upon them in medieval society. The male disguise enabled them to expose themselves to the perils of travelling, which had its risks for men as well, but not to the same extent as for women. Men risked losing life, money and goods, whereas the main risk for women, as comes across in Sefer Chasidim, was that of sexual assault.

It is also interesting to note that the Christian contemporary of Sefer Chasidim, Thomas Aquinas, agrees completely with the author of Sefer Chasidim concerning this type of crossdressing: it was allowed in what might be called a 'state of emergency', which would then override the prohibition.

\section{Dressing as gentiles}

The prophet Zephaniah explicitly prohibits donning the style of dress of the gentiles:

And on the day of the Lord's sacrifice I will punish the officials and the king's sons And all who dress themselves in foreign attire [מלבוש נכרי]. (Zeph. I:8) 
Concerning the general question whether Jewish men are allowed to disguise themselves as gentiles, Sefer Chasidim gives the following advice: a Jew is not allowed to wear a cross or to disguise himself as a priest, but he is permitted to dress like a gentile for the purpose of safety while on the road, as long as the clothes do not contain shaatnez, a combination of wool and linen, forbidden by Leviticus r9:19 and Deuteronomy 22:I I (Wistinetzki I924: \$2025; Margaliot I957: § I99). 9 There was a difference of opinion on this matter among the medieval Ashkenazi scholars. The eleventh-century commentator Rashi interprets 'foreign attire [מלבוש נכרי]' as 'the jewellery/adornments of the idolators [סעכו תכשיטי"]', not as a reference to clothing, which would leave the door open for dressing as gentiles, if need be (Rashi ad loc.). The regulations accepted by the Jewish communities in Speyer, Worms, and Mainz in the thirteenth century (takkanot Shum), however, explicitly forbid dressing like gentiles (Rubens i 967: 94).

Sefer Chasidim also explicitly addresses the passage in Zephaniah concerning Jews who during persecutions had donned non-Jewish clothing in order to escape. Did they need to make atonement for this? The answer, according to Sefer Chasidim, depends on whether it was premeditated or not. If a person had planned to adopt this strategy, he should have prepared clothing without shaatnez ahead of time. If, in spite of having planned this, he had made no such preparations, and therefore had been forced to wear shaatnez, he had to make atonement. If, on the other hand, it was not premeditated, he did not need to make atonement for wearing shaatnez, if it was done out of dire necessity, in order to save his life (Wistinetzki I924: §203; Margaliot I 957: § I99). From this passage there

9 The Wistinetzki edition explicitly states 'cross'; the Margaliot edition has 'any jewellery/ornament [תכשיט]'. does not seem to have been a need for atonement for dressing as a Christian, merely for wearing shaatnez.

Other more general prohibitions against adopting the behaviour of the gentiles (Lev. I 8:3, 20:23; Deut. I 2:30) were in post-talmudic times also interpreted as prohibitions against wearing the clothes of the gentiles (Yeivin et al. 2007: I4). Still, the fact that both Muslim and Christian societies prescribed a distinctive dress for the Jews during the Middle Ages indicates that prior to such ordinances, the Jewish dress in many areas probably resembled that of the local non-Jews in most respects.

Important for understanding the passages in Sefer Chasidim quoted above are the regulations for Jewish dress passed by the Fourth Lateran Council in I 2 I 5 . These regulations ordered Jews and Muslims to wear a distinctive dress against the background that in some places they could no longer be distinguished from Christians by their dress. The explicit motive for this is that Christians should not unwittingly have sexual relations with Jews and Muslims (Grayzel I 933: X). In a document from the council it is stated that in certain provinces Christians can be distinguished from non-Christians by their clothing, in others this is not so. This document also notes that distinctive clothing is something which was decreed already by Moses (ibid.).

In the wake of this council regulations appear, passed by subsequent local councils, as well as papal letters addressing the same issue. Sometimes the Jews are to wear distinguishing clothing, sometimes a 'Jewish badge'.10 A brief survey of these papal and conciliar documents

10 See for instance Letter by Innocent III, I 2 I 5-I6, to the archbishops and bishops of France (Grayzel I933: 3 I); Letter by Honorius III, I 2 I 7 , to the Bishop and Abbot of Fusiliens (Simonsohn I988: Husillos, Palencia), and the Dean of Toledo (Grayzel I 933: 33; Simonsohn I 988: 96); the Council of Oxford, I 222 (Grayzel I 933: XVI); Letter 
reveals an interesting emphasis: most of them deal with areas in what is today Spain and France. Present-day Germany, the area which was the heartland of Chasidei Ashkenaz, is notably absent from these documents. Why might this be? The simplest reason seems to be that there was no problem in this area: that, as is indicated in the passages from Sefer Chasidim, it was possible to distinguish Jews and Christians by the way they dressed, unlike in many other parts of Europe, which then merited the attention of church councils and popes. ${ }^{11} \mathrm{~A}$ particular

by Honorius III, I 2 I 8 , to the Archbishop of Toledo (ibid. 36; Simonsohn I 988: 99); Letter by Honorius III, I 2 I 9, to the Archbishop of Toledo (Grayzel I 933: 38; Simonsohn I988: I02); Letter by Honorius III, I 22 I, to the Archbishop of Bordeaux (Grayzel I933: 49; Simonsohn I988: I I 3); Council of the Province of Narbonne I 227 (Grayzel I 933: XVIII); Council of Valladolid, I 228 (ibid. $\mathrm{XX}$ ); Council of the Province of Rouen I23 I (ibid. XXV); Letter by Gregory IX to the Archbishop of Compostella, I 233 (ibid. 7 I; Simonsohn I 988: 137); Letter by Gregory IX, I 233, to the King of Navarre (Grayzel I933: 72; Simonsohn I988: I 36); Letter by Gregory IX, I234, to the King of Navarre (Grayzel I 933: 78); Council of Arles, I 234 (ibid. XXIX); Council of Tarragona, I 239 (ibid. XXXIII); Letter by Innocent IV, I 245, to the Archbishop of Besançon (ibid. I07; Simonsohn I 988: I75); Letter by Innocent IV to the Bishop of Maguelonne, I 248 (Grayzel I 933: I 20; Simonsohn I 988: I 89); Letter by Innocent IV to the Bishop of Cordova (Grayzel I 933: I 22; Simonsohn I988: I92); Council of Albi, I 254 (Grayzel I 933: XLI); Letter by Innocent IV to the Bishop of Constance, I 254 (ibid. I33; Simonsohn I 988: 203); Letter by Alexander IV, I 258, to Hugh IV, Duke of Burgundy, Louis IX, King of France, and Charles, Count of Anjou and Provence (Simonsohn I 988: 2 I I); Letter by Clement IV to archbishops and bishops in the domains of the counts of Poitou, Toulouse, and Provence, I 267 (ibid. 232).

11 See for instance the following documents where it is explicitly stated that the Jews in that particular area do not comply with problem that is addressed in a couple of documents from France and Spain is that the Jews wore round capes that resembled those worn by Christian clerics and members of holy orders, and therefore sometimes were taken for such. 12

What did this distinguishing clothing look like? In Germany and France, the area of the Chasidei Ashkenaz, the pointed hat, the Judenhut, had become distinctly Jewish by the thirteenth century. By the same time, Jewish women in many parts of Europe were forced to wear two blue stripes in their veils (Yeivin et al. 2007: I 5).

As is often the case, the author of Sefer Chasidim, like any other theologian, could not merely state what the correct course of action is, but had rather to choose which is the greater evil, as is evident from another passage which deals with Christian 'cross-dressing'. In this text, the women actually pretend to convert, in order to escape persecution:

the decree to wear distinguishing clothing: Letter by Honorius III to the Bishop and Abbot of Fusillens in the diocese of Plasencia (Simonsohn I988: Husillos, Palencia), and to the Dean of Toledo concerning the Jews of Burgos I 2 I 7 (Grayzel I 933: 33; Simonsohn I 988: 96); Letter by Honorius III, I 2 I 8, to the Archbishop of Toledo concerning the Jews of that area (Grayzel I933: 36; Simonsohn I 988: 99); Letter by Gregory IX to the Archbishop of Compostella, concerning the Jews of that area, I 233 (Grayzel I 933: 7 I; Simonsohn I988: I37); Letter by Honorius III, I 22 I, to the Archbishop of Bordeaux concerning the Jews in that area (Grayzel I 933: 49; Simonsohn I 988: I I3); Letter by Innocent IV, I 250 , to the Bishop of Cordova concerning the Jews in that area (Grayzel I 933: I 22; Simonsohn 1988: 192).

12 Letter by Innocent IV, I 248 , to the Bishop of Maguelonne (Grayzel I 933: I 20; Simonsohn I 988: I 89); Council of Albi, I 254 (Grayzel I 933: XLI); Council of Valladolid, I 228 (ibid. XX). 
It happened during the time of forcible conversions that part of a community was killed, and the others converted, under the threat of the sword, with the intention of returning to Judaism as soon as possible.

Some married women, whose husbands had been killed resisting conversion, and some single women feared that the uncircumcised ones would rape them [lit. 'render them impure']. They then declared that they wanted to become nuns [in order to protect themselves]. But they did not take their small daughters with them [into the convent] because if they were to escape they would not leave the children behind. Other women resorted to wearing black dresses and stayed at home, thinking: 'If we are to become like nuns, we won't be able to escape soon.' The gentiles told them: 'Either you join the convent or you must wear white dresses.'They put on white dresses because they said: 'If we are in the convent we won't be able to escape soon.'The rabbis who were among them told the women: 'If you are sexually defiled against your will, it is not as grave an offence as going into the convent, because the women who are in the convent will be watched for many years so that they will not escape. Meanwhile, they are forced to eat forbidden foods and desecrate the Sabbath. However, if the uncircumcised ones should force a woman to marry one of them, she will never be able to escape, because her husband will watch over her. In that case, it is preferable that she enter a convent rather than that an uncircumcised one should defile her.' (Wistinetzki I 924 : \$262; Margaliot I 957: §703)

There are several difficulties in this text. What is implied by the fact that they wore black dresses, but that the Christians wanted them to wear white? Does it mean that they were widows who signalled that they were in mourning?
Were these women who under duress had allowed themselves to be baptised, whereas their husbands had been killed, resisting forcible conversion? Had the women planned to spend the period of persecution as mourning widows, a way of escaping being married to a Christian, and once the persecutions had abated, they would return to Judaism, something that would be difficult if in the meantime they had been married to a Christian? Is this what is signalled through the options that are given by the Christians: enter a convent or take off your mourning clothes, and make yourselves available for marriage? 13 Such an interpretation seems to fit well with the quoted response from the local rabbis, that they should avoid marriage since it was the worst option, in their opinion. We could also note that in the early church and in the Middle Ages, the dress of widows was often very similar to the monastic habits of nuns: they wore plain clothes, often black or brown. The clothes were deliberately intended to hide their feminine forms. They were not to be perceived

13 In his translation of selected parts of Sefer Chasidim, Avraham Yaakov Finkel understands the text differently. He claims that 'wearing black dresses' meant that they were to dress like Christians, and that the Christians wanted them to wear white dresses, in order to make them easier to spot, should they try to escape (Finkel I997: 358). Note that my interpretation that discarding their black dresses in favour of white ones should not necessarily be understood as seeing the white dress as a reference to a wedding dress, since the custom of wearing white as a wedding dress was not established at this time. There were no particular wedding clothes at this time. Rather, medieval couples of different standings simply wore the best they had. From a later date (fifteenth century), however, it is attested from the Rhineland that both bride and groom wore a full-length overgarment of white linen. It is of course possible that this was done at the time of Sefer Chasidim as well, but not documented (Piponnier and Mane 1997: I IO-II). 
as fashionable but rather as unchanging (Taylor I983). 14

What is clear, however, is that there is a certain hierarchy of evils. The worst option is that a Jewish woman should marry a gentile. The second worst is to enter a convent. Interestingly, here the best option seems to be to be raped. It seems that what is at stake here is the duration of the transgression. Being married to a gentile is similar to living in a convent in the sense that it entails being forced to regularly commit sins such as eating forbidden food and desecrating the Sabbath. The difference between the two options is not that one is chaste (convent) and the other unchaste (marriage to a gentile) but the duration of this state of $\sin$. In the case of the convent, the women are expected to be able to escape sooner than in the case of marriage to a watchful husband. This also means that the unchaste option of rape is to be preferred to the chaste option of entering a convent, since the rape is a passing occurrence but staying in a convent would be expected to be of longer duration. We could also note that the author of Sefer Chasidim does not differentiate between an act done to the woman, such as rape, and acts which the woman would have to consent to, such as entering a convent or marrying a gentile.

14 Medieval monastic orders could in theory be distinguished by their habits, but in practice there was plenty of variation within the orders as well: Benedictine nuns were referred to as Black Ladies but many Augustinian canonesses also wore black habit. Cistercian nuns were referred to as White Ladies but white was also worn by Premonstratensian nuns. The reformed Benedictine orders (Humiliati, Fontevrault, Cistercian, Carthusian, Vallombrosan, Olivetan and Sylvestrine) followed St Benedict's recommendation of wearing the cheapest, local and undyed woollens, which in medieval depictions of these orders range from brown to bleached white (Koslin 2001: 262-2).
It is interesting to note that just as Sefer Chasidim states that it is allowed to break the prohibition against dressing like a non-Jew if that means saving one's life or virtue in this way, there is also at least one example of a similar permission on the Christian side. In a papal letter from Innocent III, written shortly after the Fourth Lateran Council (I 2 I5), he orders the archbishops and bishops of France to enforce the ordinations that the Jews should wear clothes that distinguish them from Christians. They should not, however, be forced to wear anything that would endanger their lives (Innocent III, I 2 I5-I6) (Grayzel I 933: 3 I; Simonsohn I 988: 94). There could also be other reasons for suspending the rule about distinguishing clothing. In a letter by Honorius III to the archbishop of Toledo, written in I 2 9, the pope gives the archbishop permission to suspend the decree on distinguishing clothing as long as he sees fit. The reason for this is that the decree has made many Jews flee to areas under Muslim rule, which has meant a considerable loss of income for the king (Honorius III, I2 I9) (Grayzel I933: 38; Simonsohn I988: 102).

To summarise: these passages from Sefer Chasidim should be seen against the background that Jewish and Christian sources in principle prescribe that Jews should wear clothes that distinguish them from non-Jews, or, put differently, that non-Christians must be distinguished from Christians. We can also note that there is a contradictory, sexual component in this matter. Christian sources claim that Jews should wear distinguishing clothing in order to prevent illicit sexual contacts between Jews and Christians. Sefer Chasidim makes allowance for the opposite, for Jews to renounce their distinguishing clothing and dress as Christians, in order to prevent such contacts. In this case as well, it is interesting to note that just as Sefer Chasidim allows this otherwise forbidden practice if it serves a greater cause under certain circumstances, likewise there are papal documents that annul the 
decree for distinguishing clothing for a greater cause, be it to save the lives of these Jews or to save the finances of the king.

\section{Binary categories}

Judith Butler has in several of her works stressed the performative nature of gender distinctions, that female and male gender is something which is not primary, but rather something which requires being created and re-created through repetitive acts, speech acts and other types of acts. Through the creation of the female and the male, acts and discourse maintain a clear distinction between the two, and preclude the existence of anything that cannot be sorted into one or the other of the two categories. Butler criticises the distinction that is often made in modern feminism between 'sex' and 'gender', since it usually implies that whereas 'gender' is culturally constructed, 'sex' is a stable, binary, and prediscursive distinction (Butler r 999: 9-I I). Butler sees the body as "not a "being", but a variable boundary surface whose permeability is politically regulated, a signifying practice within a cultural field of gender hierarchy and compulsory heterosexuality' (ibid. I77).

Although the binary system requires constant recreation, it still maintains itself as primary, natural and eternal. Butler writes:

In other words, acts and gestures, articulated and enacted desires create the illusion of an interior and organizing gender core, an illusion discursively maintained, for the purposes of the regulation of sexuality within the obligatory frame of reproductive heterosexuality. If the 'cause' of desire, gesture, and act can be localized within the 'self' of the actor, then the political regulations and disciplinary practices which produce that ostensibly coherent gender are effectively displaced from view. (Butler I999: 173-4)
Superficially gender-reversing cross-dressing may seem to challenge this binary system, when people, albeit only temporarily, can cross over into the other category. Still, upon closer examination, rather the contrary seems to be the case. This type of gender-reversing cross-dressing consolidates the binary gender distinction by precluding any category in between. Men are men although under certain circumstances young men can temporarily disguise themselves as women, but it is taken for granted that when the special circumstances have passed they will revert to their original group. The same is true for women who temporarily, under certain circumstances, could cross over into the male group, as women in disguise, appearing to be men. They are to gird themselves with swords 'to make them [= the non-Jews] think that they are men and thus not harm them'. They are not given permission to become fighting women and thus challenge the distinction between the two categories: women as unarmed and non-fighters, and men as armed and fighters. Women must not put on men's apparel; instead they become temporary men. We can note that this differs from Joan of Arc, who wore men's clothing, but other than that did not disguise the fact that she was a woman, but rather claimed to be a fighting woman, the 'maiden of Orleans'.

It is interesting to note that scholars have observed similar reluctance to accept fighting women in Christian sources that describe Christian women who took an active part in battles during the crusades. Either they are portrayed as merely performing menial tasks for the men who are doing the real fighting, or they are described in a humorous way, armed with objects associated with female life, for instance with a cooking pot for a helmet. That way the basic categories of men as fighters and women as non-fighters are not challenged. The rendering of the Christian sources can also be seen in contrast to Muslim sources, who describe Christian women who actually fight like men (Nicholson 
1997, Edgington and Lambert 2001, Kostick 2005).

The same analysis can be made for religion-reversing cross-dressing. Jews are Jews and Christians are Christians, although under special circumstances some Jews can be allowed to disguise themselves as Christians and temporarily cross over to the category of Christians, always, however, as Jews in disguise, never as Christians. Another option might have been to suggest that Jews might opt to travel in the company of Christians, in order to be more secure, but that option is not chosen. In the same way as for gender-reversing cross-dressing, the option of disguising as Christians actually reinforces the idea that Jews and Christians are two distinctly separate groups, with nothing in between. The type of cross-dressing discussed in these texts can be understood as a ferry which goes between two shores, without the possibility of stopping in between the two, so to speak, in mid-water.

But if we are to claim that this practice and the discourse around it served to strengthen the idea that Jews and Christians as well as women and men were two stops in a ferry line, or, in the understanding of Butler, two coherent poles in a binary system with nothing in between, we would have to examine whether there are any signs that there were those who in deeds or discourse advocated a position in between the two. Are there any voices that challenge the binary system?

In fact, that seems to have been the case, both when it comes to women-men and JewsChristians. We shall start with the distinction between women and men. It is attested in earlier scholarship that Ashkenazi Jewish women during the High Middle Ages showed a tendency to assume religious responsibilities that were according to traditional halacha incumbent merely on men, for instance reciting the blessing over time-linked commandments, reclining during the seder meal of Passover, wearing ritual fringes (zitzit) and phylacteries (tefillin) (Grossman 2004: I78-80, I 88, I 94). Most Ashkenazi sages during this period accept these developments, although by their commentaries it is sometimes evident that these are changes that the women themselves have initiated, and that the sages have merely declared them acceptable after the fact. Avraham Grossman (2004: I77, 274-6) links this development to two factors:

I. Similar developments in the contemporary Christian world, with new forms of piety for women, new religious orders and the emergence of the beguine movement.

2. The strong position of these Jewish Ashkenazi women during this period, socially and economically.

There were, however, reactions to the Ashkenzi women's claim to increased religious participation. During the course of the thirteenth century the objections to women performing mitzvoth that are traditionally seen as obligatory only for men become increasingly forceful. Elisheva Baumgarten has studied the development of the role of ba'al brit/sandaq (or for women ba'alat brit/sandeqet or sandaqit), the person who held the infant boy during the ritual circumcision. This role seems to have gained importance during the twelfth and thirteenth centuries, possibly as a parallel to the development of the role of godparents in the Christian baptism. Sometimes a man, sometimes a woman was appointed to the honourable role of ba'al/ ba'alat brit. At the end of the thirteenth century, however, we find protests against the fact that women were appointed to this role. In Sefer Tashbetz by R. Samson ben Tzadok, a student of R. Meir ben Barukh of Rothenburg (d. I 293), R. Samson protests against a custom which is practised 'in most places', that is that a woman should act as ba'alat brit. He objects to this on two accounts: because this meant that she would 
enter into the male section of the synagogue where the circumcision took place, and because it was not the women but the men who had been commanded by God to circumcise the sons (Gen. 17:23). By doing this, R. Samson writes the women 'snatch this commandment from the men' (Baumgarten 2004: 65-89). This seems like an odd way of interpreting the commandment to circumcise all male children among the Israelites. The commandment does not mention the role of the ba'al brit. Rather its aim seems simply to be that the father should procure that the male infants are circumcised.The most obvious explanation for the strong reaction against the women who served as ba'alot brit seems to be that it challenged the distinction between men and women. By entering into the male section of the synagogue and taking active part in a religious obligation that according to tradition was only incumbent upon Jewish men, women approximated the religious status of men, and blurred the borders between the two groups. This could also be related to Daniel Boyarin's discussion on sexual acts forbidden by the Torah in his article 'Are there any Jews in the "History of Sexuality"?'There he convincingly shows that the prohibition against male-male anal intercourse in Leviticus should not be seen as a prohibition against homosexuality, but rather as a prohibition against men taking the position of a woman during intercourse. Boyarin therefore relates this prohibition to other prohibitions against mixing two separate categories or transcending the borders between them, for instance the prohibition against planting two different species together, of combining wool and linen (shaatnez, see above), of mating a horse to a donkey, or of cross-dressing. The overriding purpose of all these prohibitions is maintaining clear and distinct categories (Boyarin I 995: 342).

This understanding of R. Samson's negative reaction is strengthened by the fact that other expansions of traditional piety met with favourable reactions, as long as these expansions rather served to strengthen the distinction between men and women. For instance, women, who participate in prayer in the synagogue, are commented upon favourably by Sefer Chasidim as well as by other contemporary Ashkenazi sources. Some of these sources use the term 'women's synagogue', indicating that the women prayed in a synagogue that was not merely a building which had separate sections for men and women but in effect a separate building for women. In it, some women also served as cantors for the women (Grossman 2004: I 80-2).

Another such development at this time and in this region is that increasingly women did not attend synagogue during menstruation, a practice that increased at the end of the twelfth century, when the influence of Chasidei Ashkenaz was growing. Several contemporary Ashkenazi scholars cite this approvingly, stressing that it was the women themselves who adopted these customs (Grossman 2004: I 83-4). Unlike the women who expanded their religious obligations by assuming commandments traditionally only applying to men, this form of religious piety rather strengthened the image of men and women as two separate and distinct categories.

It therefore seems that there is a negative development when it comes to the religious participation of Ashkenazi women during the thirteenth century. After a period of increased ritual participation where women participated in rituals that were traditionally performed only by men, this is increasingly criticised during the thirteenth century. Elisheva Baumgarten understands this as a parallel to a similar development in the surrounding Christian society, where after a period of increased participation through lay piety and female orders, church authorities seemed determined to limit women's religious functions, by reproaching women who preached and criticising religious practices that were important in the lives of religious women, such as fasting (Baumgarten 2004: 88). From the point of view of Butler's theory of performative 
acts and discourse, this can be seen as regulatory practices that strive to uphold binary gender poles with nothing in between.

What about the distinction between Jews and Christians? A well-known figure in Christian theological discourse is the prohibition on 'judaising' the Christian faith, that is, turning it into a form of Judaism by maintaining some Jewish practices that are supposed to have become obsolete through Christianity, for instance celebrating Jewish festivals, observing Sabbath, or following Jewish dietary laws. 15 But there are also indications from the other side that there were some Jews who seem to have been attracted by some Christian practices. This is for instance the case in the following passage from Sefer Chasidim:

A man should not say: 'Since envy, lust and ambition are an evil path and lead to a man's ruin I will go as far as possible in the other direction.' He goes so far as not to eat meat, not to drink wine, not to live in a decent house or wear decent clothes, but dresses in sack and a coarse shirt etc. as Christian monks do. You should know that this is also an evil path. It is forbidden to follow it but you must stay away from it. Those who follow it shall be called sinners. 16

15 See for instance the following documents: Collectio Vetus Gallica (canonical collection, compiled between 585 and 626/7), 55:I; Collectio Hispana (exists in three different recensions, composed between 633-694/702), C. 29; Ivo of Chartres, Decretum (c. I094/5), I $1: 35$, all reproduced in Linder I 997: 568 , 572 and 660 , respectively. See also a letter by Clement IV, I 267 , instructing inquisitors, Dominicans and Franciscans to proceed against judaizing Christians (Simonsohn I 988: 230).

16 I have only found this passage in the Margaliot edition (1957: §52).
It is true that the wine is required for certain Jewish rituals, for instance during the Passover seder, or for the blessing over wine on the Eve of Sabbath, but other than that the balacha would not force a person to eat meat, dress well or live comfortably, and occasionally abstaining from such pleasures would have been seen as a sign of piety. The key to understanding why the author of Sefer Chasidim saw this form of asceticism as sinful probably lies in the short phrase 'as Christian monks do'. We should probably interpret this prohibition as an indication that among the Ashkenazi Jews there were those who were attracted by the ascetic lifestyle of Christian monastics and who wanted to emulate it. Following Butler, this could be seen as something that challenged the binary system, and the condemnation of it should be seen as a way to reinforce the basic two categories and condemn any position in between.

There are other examples from Sefer Chasidim of practices that seem to be inspired by Christian practices, and that are condemned. So for instance the practice of invoking angels for protection before going on a journey, instead of praying to God, is condemned (Wistinetzki I 924: §205; Margaliot r 957: §623). This could be a parallel to the Christian practice of invoking saints for protection, for instance $\mathrm{St}$ Christopher, patron saint of travellers.

There are also passages in Sefer Chasidim that seem to portray Jewish converts to Christianity as a category somewhere between Jews and Christians. So, for instance, such a convert may contribute to the costs of producing a new Torah scroll for the synagogue, since it may be gratifying for his family when people say 'Although he is an apostate, deep in his heart he is still a Jew' (Wistinetzki r 924: §687; Margaliot I 957: §628). 17

17 Other cases are also cited when converts to Christianity perform meritorious deeds, for instance saving holy books or burying a Jew 
There are also passages that stress the importance of distinguishing between Jews and Christians. For instance, if a Jewish man is taken for a gentile, he must declare that he is a Jew (Wistinetzki I924: § I I7; Margaliot I957: $\$ 64 \mathrm{I})$. If threatened by approaching crusaders Jewish men are not allowed to wear crosses on their clothing, to dress or to shave their heads like Christian clergy. The same passage also prohibits Jews who run into Christians on their way to church from going along with them, pretending to be gentiles. In this last prohibition there is no mention of the fact that the gentiles might pose any threat to the Jews, which would explain their pretending to be Christians, but maybe it can be assumed that that is what is intended from the context (Wistinetzki I924: \$2 I; Margaliot I957: 6445 ).

Various passages also mention that tunes could be appropriated by both groups. So for instance Jews are forbidden to teach a priest beautiful Jewish songs, since he might use that melody in the Christian service. Likewise Jews are forbidden to use tunes from church music in their prayers (Wistinetzki I924: \$238; Margaliot I 957: §646).18

It is therefore clear that the borders between Jews and Christians in the world of Chasidei Ashkenaz were at times unclear.

The discourse found in Sefer Chasidim on the possibility of temporary cross-dressing, as Christians or as the other sex, in order to avoid dangers, can be seen in three ways:

who dies without any relatives to care for his burial (Wistinetzki I 92 4: §859-6o; Margaliot I957: $\$ 635$ ).

18 See also Wistinetzki I 924: $\$ 428$, Margaliot 1957: 657 which prohibits translating a poem composed by a monk or a church hymn into Hebrew and using it in Jewish prayer.
I. As describing the reality of perils Jews ran the risk of encountering and a ways they used to avoid these risks.

2. As a discourse that reflects anxieties around the fact that the borders between Jewish men and Jewish women, as well as between Jews and Christians, were sometimes unclear and/or contested.

3. Therefore: instead of challenging the categories of men/women, Jews/Christians, this discourse on cross-dressing actually serves to uphold the basic structure of binary categories, by describing it as if it were a ferry line with only two stations and no in-between stops.

Lena Roos is associate professor of History of Religions, Uppsala University, where she is also one of the co-directors of the Forum for Jewish Studies. Her research interests are, for example, Jewish-Christian relations, Judaism (medieval, Early Modern, contemporary), religion and sexuality, religion

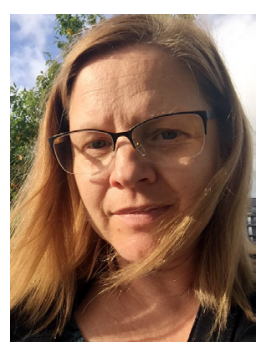
and food, religion and popular culture, teaching religion. Her recent publications include 'If I am only for myself, who am I?' in Religion and Volunteering: Complex, Contested and Ambiguous Relationships (eds. Lesley Hustinx et al., Springer 2015) and 'Gottlieb Klein und die Religionswissenschaft in Schweden' in Deutschsprachige jüdische Migration nach Schweden (de Gruyter 2017).

\section{References}

\section{Sources}

Burchard of Worms, I996. Decretorum libri viginti, Patrologia Latina Database, vol. I 40 (Alexandria, VA, Chadwyck-Healey)

Finkel, Avraham Yaakov (ed. and transi.), 1 997. Sefer Chasidim: The Book of the Pious (Northvale, NJ, Aronson)

Gratian, I 996. Decretum, Patrologia Latina Database, vol. I 87 (Alexandria, VA, ChadwyckHealey).

Grayzel, Solomon, 1933. The Church and the Jews in the XIIIth Century: A Study of their Relations during the Years 1198-1254, Bases in the Papal Letters and the Conciliar Decrees of the 
Period (Philadelphia, The Dropsie College for Hebrew and Cognate Learning)

Linder, Amnon (ed. and transl.), 1997. The Jerws in the Legal Sources of the Early Middle Ages

(Detroit, Wayne State University Press)

Margaliot, Reuven, I957. Sefer Chasidim (Jerusalem, Mosad HaRav Kook)

Simonsohn, Shlomo, 1988. The Apostolic See and the Jerws: Documents: 492-1404, Studies and Texts, 94 (Toronto, Pontificial Institute of Mediaeval Studies)

Thomas Aquinas, 1964-8 I. Summa Theologiae, ed. Thomas Gilby/Blackfriars (London, Eyre \& Spottiswoode)

Wistinetzki, Jehuda, I 924. Sefer Chasidim, Das Buch der Frommen (Frankfurt a. M., M. A. Wahrmann)

\section{Literature}

Baumgarten, Elisheva, 2004. Mothers and Children: Jerwish Family Life in Medieval Europe (Princeton and Oxford, Princeton University Press)

-20 15. Practicing Piety in Medieval Ashkenaz: Men, Women, and Everyday Religious Observance (Philadelphia, University of Pennsylvania Press)

Boyarin, Daniel, I995. 'Are there any Jews in "The History of Sexuality"?', Journal of the History of Sexuality, 5(3), pp. 333-55

Bullough, Vern L., 2000. 'Cross dressing and gender role change in the Middle Ages' in Handbook of Medieval Sexuality, eds. Vern L. Bullough and James A. Brundage (New York, Garland), pp. 223-42

Burns, E. Jane, (ed.), 2004. Medieval Fabrications: Dress, Textiles, Clothwork, and Other Cultural Imaginings, The New Middle Ages (New York and Basingstoke, Palgrave Macmillan)

Butler, Judith, I 999. Gender Trouble: Feminism and the Subversion of Identity (New York, Routledge)

Crowfoot, Elisabeth et al., I 992. Textiles and Clothing c.1150-c.1450, Medieval Finds from Excavations in London, 4 (London, Boydell)

Dan, Joseph, 2007. 'Sefer Hasidim'. Encyclopaedia Judaica, 2nd edn, vol. 8, pp. 392-3

Dan, Joseph et al., 2007. 'Hasidei Ashkenaz', Encyclopaedia Judaica, and edn, vol. 8, pp. 386-9

Edgington, Susan B., and Sara Lambert (ed.), 2001. Gendering the Crusades (Cardiff, University of Wales Press)

Elliott, Dyan H., I 99 I. 'Dress as mediator between inner and outer self: the pious matron of the High and Later Middle Ages', Medieval Studies, 53, pp. 279-308

Garber, Marjorie, I 992.Vested Interests: Crossdressing and Cultural Anxiety (New York \& London, Routledge)

Grossman, Avraham, 2004. Pious and Rebellious: Jerwish Women in Medieval Europe (Waltham, MA, Brandeis University Press)

Heller, Sarah-Grace, 2007. Fashion in Medieval France, Gallica, 3. (Cambridge, Brewer)

Hotchkiss, Valerie R., I 996. Clothes Make the Man: Female Cross Dressing in Medieval Europe, The New Middle Ages, I (New York \& London, Garland)

Houston, Mary G., I 939. Medieval Costume in England and France: The 13th, 14th and 15th Centuries, A Technical History of Costume, vol. 3 (London, Adam \& Charles Black)

Kanarfogel, Ephraim, I992. Jerwish Education and Society in the High Middle Ages (Detroit, Wayne State University Press)

Koslin, Désirée, 200 I. 'The robe of simplicity: initiation, robing, and veiling of nuns in the Middle Ages' in Robes and Honor: The Medieval World of Investiture, ed. Stewart L. Gordon (New York, Palgrave), pp. 25 5-74

Kostick, Conor, 2005. 'Women on the First Crusade: prostitutes or pilgrims' in Victims or Viragos, eds. Christine Meek and Catherine Lawless, Studies on Medieval and Early Modern Women, 4 (Dublin, Four Courts Press), pp. 57-68

Nicholson, Helen, I 997. 'Women on the Third Crusade', Journal of Medieval History, 23(4), pp. 335-49

Peters, Ursula, I 999. 'Gender trouble in der mittelalterlichen Literatur. Mediävistische Genderforschung und Crossdressing-Geschichten' in Manlîchiu wïp, wïplich man. Zur Konstruktion der Kategorien 'Körper' und 'Geschlecht' in der deutschen Literatur des Mittelalters, eds. Ingrid Bennewits and Helmut Tervooren, Beiheft zur Zeitschrift für deutsche Philologie, 9 (Berlin, Erich Schmidt Verlag), pp. 284-304 Piponnier, Françoise, and Perrine Mane, I 997. Dress in the Middle Ages (New Haven and London, Yale University Press)

Rubens, Alfred, I 967. A History of Jewish Costume (London, Vallentine, Mitchell)

Soloveitchik, Haym, 2002. 'Piety, Pietism and German Pietism: "Sefer Hasidim I" and the influence of Hasidei Ashkenaz', The Jerwish Quarterly Review, 92(3/4), pp. 455-93 
Taylor, Lou, I 983. Mourning Dress: A Costume and Social History (London and Boston, G. Allen and Unwin)

Vedeler, Harold Torger, 2008. 'Reconstructing meaning in Deuteronomy 22:5: gender, society, and transvestitism in Israel and the Ancient Near East', Journal of Biblical Literature, I $27(3)$, pp. 459-76

Vavra, Elisabeth, I988. 'Kritische Bemerkungen zur Kostümliteratur' in Terminologie under Typologie mittelalterlicher Sachgüter. Das Beispiel der Kleidung, ed. Harry Kühnel, Veröffentlichungen des Instituts für mittelalterliche Realienkunde Österreichs, Io (Wien, Verlag der österreichischen Akademie der Wissenschaften), pp. 2 I-45

Wilckens, Leonie von, I988. 'Terminologie und Typologie spätmittelalterlicher Kleidung. Hinweise und Erläuterungen', Terminologie under Typologie mittelalterlicher Sachgüter. Das Beispiel der Kleidung, ed. Harry Kühnel, Veröffentlichungen des Instituts für mittelalterliche Realienkunde Österreichs, Io (Wien, Verlag der österreichischen Akademie der Wissenschaften), pp. 47-57

Weichselbaumer, Ruth, 1999. 'Er wart gemerket unde erkant/durch seine unvroweliche Site. Männliches Cross-dressing in der mittelhochdeutschen Literatur' in Manlîchiu wïp, wïlich man. Zur Konstruktion der Kategorien 'Körper' und 'Geschlecht' in der deutschen Literatur des Mittelalters, eds. Ingrid Bennewits and Helmut Tervooren, Beiheft zur Zeitschrift für deutsche Philologie, 9 (Berlin, Erich Schmidt Verlag), pp. 326-4I Yeivin, Zeev, Alfred Rubens and Miriam Nick, 2007. 'Dress', Encyclopaedia Judaica, 2nd edn, vol. 8, pp. I $2-$ I 7 